\title{
Primary Schools Teachers' Motivation and Performance Improvement Gained through the Principals' Leadership 3.0 Policy Implementation
}

\author{
Tukiyo $^{1}$, J Nurkamto ${ }^{2}$, Siswandari ${ }^{2}$, and Gunarhadi ${ }^{2}$ \\ ${ }^{1}$ Doctoral Student of Education Science, Universitas Sebelas Maret, Surakarta, Indonesia \\ ${ }^{2}$ Universitas Sebelas Maret, Surakarta, Indonesia
}

tukiyo@student.uns.ac.id

\begin{abstract}
This study aims to measure primary school teachers' motivation and performance that have conditionally been improved through the implementation of principals' Leadership 3.0 policy. Eighty $(n=80)$ primary school teachers participated as the respondents with the composition of forty $(n=40)$ respondents participated as the experimental groups, whilst other forty $(n=40)$ respondents dealt with the control groups. Data were collected from the questionnaire distribution. Data analysis used the quantitative method that interpreted the descriptive statistics, chi-square for goodness of fit test, and factor analysis. The results proved that both teachers' motivation and performance achieved significantly at the level of $\mathrm{p}<.05$. Teachers' motivation showed $(\mathrm{t}=19.434 ; \mathrm{p}=.000)$ for the pre-test and $(\mathrm{t}=$ 20.708; $\mathrm{p}=.000$ ) for the post-test, whilst teachers' performance showed $(\mathrm{t}=24.190 ; \mathrm{p}=.000)$ for the pre-test and $(\mathrm{t}=27.034 ; \mathrm{p}=.000)$ for the post-test. Further, the chi-square test proved that there was no significant difference between the experimental and control group and the factor analysis result showed that the principal component analysis (PCA) undertook the presence of six dimensions with the eigen value outreaching 1 , determining $41.7 \%, 33.9 \%, 20.5 \%, 3.9 \%, 5.7 \%$, and $1.8 \%$ of the variance. This study concludes that the principals' leadership 3.0 policy implementation enhance the improvement of primary teachers' motivation and performance during their services at schools.
\end{abstract}

Keywords: Principals' Leadership 3.0; Work Motivation; Teacher Performance; Primary School Teacher 


\section{INTRODUCTION}

One of the principals' duties in the educational leadership is to arouse and increase the motivation on the effort of enhancing teachers performance. Having a high motivation, teachers are expected to gain a better performance in the teaching and learning competence. Teachers' performance are due to the connected teaching and learning activities experienced in the classroom [1]. The leadership in a school organization had better concern with teachers' motivation and performance to support their teaching quality professionally and wisely [2] through the globalization era in order to maximize the contributing aspects on the instructional curriculum, information technology, professional, social, and environmental relationships in both local and wider scopes, and teaching professionalism maintenance [3].

The principals also need to deal with a good supervision on teaching and learning since this can influence their performance [4]. However, this relates to the leadership that becomes an important factor towards teachers' motivation enhancement [5]. Leadership style may influence school innovation which is important to carry out the changes of increasing the school quality [6]. Furthermore, to enhance any educational issues at schools, it is needed to do the reflective actions from all elements, such as the principal, school-supervisors, and teachers [7]. In this particular, teachers' motivation and performance will be influenced by self-actualization, social and psychological factors internally and externally, self-esteem, jobs desired, and works wealth $[8]$.

Some studies reflected teachers' motivation and performance that constituted with its inappropriateness factors were still on day-to-day's teachers' concerns. In fact, the primary school teachers' motivation in Ankara, Turkey indicated low category [9]. Next, a research in West Romania said that most the elementary school teachers had a low motivation and unsatisfactory works [10]. Meanwhile, teachers' performance as revealed in Sleman District, Indonesia showed unsatisfactory teaching performance although they had professionally been granted by the teaching certification program[11]. Seeing this condition, teachers' motivation and performance are set in the priority to improve within the principals' leadership policy intervention. This research attempts to propose the leadership 3.0 policy that promotes Sampson's six leadership dimensions on the physicality, intellectuality, emotionality, sociability, personability, and moral ability [12], in order to measure the primary school teachers' motivation and performance that have conditionally been expected to improve throughout the implementation of principals' leadership 3.0 policy.

Hence, this present study proposes two research questions (RQs) relating to the primary school teachers' motivation and performance that conditionally improve within the implementation of principals' leadership 3.0 policy, as follows: RQ1.1: Does the principals' educational leadership 3.0 contribute an improvement towards the primary school teachers' motivation and performance in the classroom? RQ1.2: What Sampson's six leadership dimensions have dominantly contributed the primary school teachers' motivation and performance?

\section{METHOD}

This study used Creswell's (2009) quasi-experimental approach that held pre- and posttest design. This approach was intentionally applied for non-randomized experimental $(n=40)$ and control groups $(n=40)$. Eighty $(n=80)$ primary teachers participated in this study. This 
study was set at twelve primary schools located in the rural areas in Klaten District, Central Java during April to July 2018. This study firstly arranged the procedure with Sampson's (2011) leaders without titles book, which guided this study into its literature review, socialized this leadership 3.0 policy to the principals in order to adopt it in their educational leadership within three months, being comprehensible stage in this research, the leadership 3.0 policy was then simultaneously updated to obtain the progress, this research analyzed both primary teachers' motivation and improvement as part of the indicative variables in line with the principals' leadership 3.0 policy, last but not least, this research aimed to synchronized measured and investigated the empirical results as shown in both experimental and control groups.

The results of Cronbach's alpha reliability were .749 for motivation and .873 for performance. The normality test was analyzed through the Shapiro-Wilk (S-W) test, where the value of $p>.05$ with one-tailed test. Out of twenty primary school teachers, the test of sample distribution data had a normal distribution. The normality test of motivation and performance were obtained through the pre-test and post-test. First, the pre-test's experimental group indicated that the primary school teachers' motivation $(\mathrm{S}-\mathrm{W}=.960 ; p=.172)$ and the primary school teachers' performance ( $\mathrm{S}-\mathrm{W}=.969 ; \quad p=.345)$. Second, the post-test' experimental group showed that the primary school teachers' motivation $(\mathrm{S}-\mathrm{W}=.976 ; p=.539)$ and the primary school teachers' performance $(\mathrm{S}-\mathrm{W}=.949 ; \quad p=.072)$. Third, the pre-test's control group indicated that the primary school teachers' motivation $(\mathrm{S}-\mathrm{W}=.954 ; p=.102)$ and the primary school teachers' performance $(\mathrm{S}-\mathrm{W}=.957 ; p=.129)$. Last but not least, the post-test's control group showed that the primary teachers' motivation $(\mathrm{S}-\mathrm{W}=.946 ; \quad p=.056)$ and the primary school teachers' performance $(\mathrm{S}-\mathrm{W}=.948 ; p=.065)$. Based on pre-test and post-test results, there were no significant difference from the expected distribution towards the factual distribution of the normality test. Hence, the normality test had a normal distribution. Further, as an inferential statistic used to asses the equality of two variable variances, the Lavene test results were homogeneous, where the value of primary school teachers' motivation was .976; $p$ $=.539$ and the primary school teachers' performance was $.948 ; p=.067$.

Data used the returned questionnaires from forty primary school teachers who were classified as the experimental groups and had gained a treatment on the principals' leadership 3.0 policy, whilst other forty primary school teachers were clustered as the control groups and they were prior to experiencing with any treatment regarding the principals' leadership 3.0. The completed and returned questionnaires were collected from the self-rated perception about the primary school teachers' day-to-day teaching performance after the principals engaged Sampson's leaders without titles, namely: physicality, intellectuality, sociability, emotionality, personality, and moral ability dimensions. The instrument consisted of closed statements with a 5 -point Likert scale ranging from 5 to 1 , in which $5=$ excellent; $4=$ very adequate; $3=$ fair, 2 = less adequate; and $1=$ poor upon six dimensions of the principals' leadership 3.0. The respondents ranged in age from 22 to 59 years old (Mage $=40.5 ; S D=26.163)$ at the time of completing the questionnaires. Data analysis used the quantitative method. The descriptive statistics, t-test, chi-square for goodness of fit test, and factor analysis were applied to measure the perceived primary school teachers' motivation and performance shown after the principals' leadership 3.0 policy were implemented.

\section{RESULT AND DISCUSSION}

The descriptive statistics findings quantitatively constituted with the primary teachers' motivation and performance results in supporting the principals' leadership 3.0 policy applying 
for Sampson's leaders without titles, shown in Table 1. The summary of descriptive statistics firstly began with the pre-test's primary school teachers' motivation undertaken in the experimental group was $(n=40 ; M=40.73 ; S D=5.522)$, whilst the control group was $(n=40$; $M=40.36 ; S D=3.555)$. Secondly, the post-test's primary school teachers' motivation undertaken in the experimental group was $(n=40 ; M=49.28 ; S D=4.296)$, whilst the control group was $(n=40 ; M=48.83 ; S D=3.580)$. Thirdly, the pre-test's primary school teachers' performance undertaken in the experimental group was $(n=40 ; M=41.53 ; S D=4.707)$, whilst the control group was $(n=40 ; M=39.30 ; S D=1.884)$. Fourthly, the post-test's primary school teachers' performance undertaken in the experimental group was $(n=40 ; M=50.40 ; S D=$ $7.052)$, whilst the control group was $(n=40 ; M=39.57 ; S D=1.810)$. Next, the hypothesis test summary had extracted the primary school teachers' achievement significantly at the level of $p<.05$ through the motivation and performance variables. However, the teachers' motivation showed $(t=19.434 ; p=.000)$ for the pre-test and $(t=20.708 ; p=.000)$ for the post-test. Meanwhile, teachers' performance showed $(t=24.190 ; p=.000)$ for the pre-test and $(t=27.034$; $p=.000)$ for the post-test.

Table 1. Primary School Teachers' Motivation and Performance

\begin{tabular}{llrrrr}
\hline \multirow{2}{*}{ Variable } & \multirow{2}{*}{ Description } & \multicolumn{2}{c}{ Experimental Group } & \multicolumn{2}{c}{ Control Group } \\
\cline { 3 - 6 } Motivation & Pre-test & Post-test & Pre-test & Post-test \\
& Mean & 40 & 40 & 40 & 40 \\
& Median & 40.73 & 49.28 & 40.36 & 48.83 \\
& Variance & 40.55 & 40.14 & 40.28 & 47.89 \\
& SD & 30.487 & 18.00 & 12.635 & 12.815 \\
& Min. & 5.522 & 4.296 & 3.555 & 3.580 \\
& Max. & 33.00 & 34.00 & 32.00 & 33.00 \\
Performance & 51.00 & 55.00 & 42.00 & 44.00 \\
& N & 40 & 40 & 40 & 40 \\
& Mean & 41.53 & 50.40 & 39.30 & 39.58 \\
& Median & 43.00 & 50.50 & 39.00 & 39.50 \\
& Variance & 22.153 & 49.733 & 3.549 & 3.276 \\
& SD & 4.707 & 7.052 & 1.884 & 1.810 \\
& Min. & 34.00 & 37.00 & 32.00 & 35.00 \\
& Max. & 52.00 & 56.00 & 43.00 & 46.00 \\
\hline
\end{tabular}

Secondly, this research also analyzed six dimensions on principals' leadership 3.0 using the chi-square goodness of fit test. This test identified responses on the experimental and control groups differences with $p=.000$. Table 2 determined the experimental group' chi-square statistics. The experimental group's chi-square was significant for physicality, $\chi^{2}(1, n=40)=$ $.900, p<.343$; intellectuality, $\chi^{2}(2, n=40)=10.650, p<.004$; sociability, $\chi^{2}(2, n=40)=15.050$, $p<.001$; emotionality, $\chi^{2}(1, n=40)=.900, p<.343$; personality, $\chi^{2}(2, n=40)=10.850, p<.004$; and moral ability, $\chi^{2}(2, n=40)=12.950, p<.0002$. 
Table 2. Experimental Group's Chi-Square Test of Principals’ Leadership 3.0

\begin{tabular}{cccccccc}
\hline & $\begin{array}{c}\text { Physica } \\
\text { lity }\end{array}$ & $\begin{array}{c}\text { Intellectuali } \\
\text { ty }\end{array}$ & $\begin{array}{c}\text { Sociabilit } \\
\mathbf{y}\end{array}$ & $\begin{array}{c}\text { Emotionalit } \\
\mathbf{y}\end{array}$ & Personality & $\begin{array}{c}\text { Moral } \\
\text { Abilit } \\
\mathbf{y}\end{array}$ \\
\hline $\begin{array}{c}\text { Chi- } \\
\text { Square }\end{array}$ & $.900^{\mathrm{a}}$ & $10.850^{\mathrm{b}}$ & $15.050^{\mathrm{b}}$ & $.900^{\mathrm{a}}$ & $\begin{array}{c}10.850 \\
\mathrm{~b}\end{array}$ & $\begin{array}{c}12.950 \\
\mathrm{~b}\end{array}$ \\
\hline Df & 1 & 2 & 2 & 1 & 2 & 2 \\
\hline $\begin{array}{c}\text { Asymp. } \\
\text { Sig. }\end{array}$ & .343 & .004 & .001 & .343 & .004 & .002 \\
\hline
\end{tabular}

a. 0 cells $(0.0 \%)$ have expected frequencies less than 5 . The min. expected cell frequency is $20.0 ; n=40$

b. 0 cells $(0.0 \%)$ have expected frequencies less than 5 . The min. expected cell frequency is $13.3 ; n=40$

Meanwhile, Table 3 showed the control group' chi-square statistics. The control group's chi-square was significant for physicality, $\chi^{2}(1, n=40)=.900, p<.343$; intellectuality, $\chi^{2}(2, n$ $=40)=10.650, p<.004$; sociability, $\chi^{2}(2, n=40)=15.050, p<.001$; emotionality, $\chi^{2}(1, n=40)$ $=.900, p<.343$; personality, $\chi^{2}(2, n=40)=10.850, p<.004$; and moral ability, $\chi^{2}(2, n=40)=$ $12.950, p<.0002$. Hence, the chi-square test for goodness of fit addressed that there was no significant difference in the proportional majority of the primary school teachers as undertaken in both experimental and control group conveyed by the current samples $(n=80)$.

Table 3. Control Group's Chi-Square Test of Principals' Leadership 3.0

\begin{tabular}{ccccccc}
\hline & $\begin{array}{c}\text { Physicalit } \\
\mathbf{y}\end{array}$ & $\begin{array}{c}\text { Intellectuali } \\
\text { ty }\end{array}$ & $\begin{array}{c}\text { Sociabilit } \\
\mathbf{y}\end{array}$ & $\begin{array}{c}\text { Emotionalit } \\
\mathbf{y}\end{array}$ & Personality & $\begin{array}{c}\text { Moral } \\
\text { Abilit } \\
\mathbf{y}\end{array}$ \\
\hline $\begin{array}{c}\text { Chi- } \\
\text { Squar } \\
\text { e }\end{array}$ & $.900^{\mathrm{a}}$ & $10.850^{\mathrm{b}}$ & $15.050^{\mathrm{b}}$ & $.900^{\mathrm{a}}$ & $\begin{array}{c}10.850 \\
\mathrm{~b}\end{array}$ & $\begin{array}{c}12.950 \\
\mathrm{~b}\end{array}$ \\
\hline Df & 1 & 2 & & & & \\
\hline $\begin{array}{c}\text { Asym } \\
\text { p. Sig. }\end{array}$ & .343 & .004 & 2 & 1 & 2 & 2 \\
\hline
\end{tabular}

a. 0 cells $(0.0 \%)$ have expected frequencies less than 5 . The min. expected cell frequency is $20.0 ; n=40$

b. 0 cells $(0.0 \%)$ have expected frequencies less than 5 . The min. expected cell frequency is $13.3 ; n=40$

Thirdly, six dimensions of leadership 3.0 indicators were subjected to the principal components analysis (PCA). Before performing these components, data suitability for the factor analysis was measured. The correlation inspection matrix revealed the coefficients presence of .107 above. The value of Kaiser Meyer-Olkin (KMO) was .612, exceeding the recommended value of .6 and Bartlett's Test of Sphericity was $p=.000$ [24] that fulfilled the statistical significance and supported the correlation matrix factorability. The PCA undertook the presence 
of six dimensions with the eigen value that outreached 1 , determining $41.7 \%, 33.9 \%, 20.5 \%$, $3.9 \%, 5.7 \%$, and $1.8 \%$ of the variance accordingly as shown in Table 4 . The scrutiny of the scree plot invented a definite part after thoroughly conveying out of six dimensions. These were calculatingly connected with the parallel outputs that solely determined two components with the eigen value towards the existing criterion values for a randomly carried on the data matrix of the size given, as if 6 dimensions timed by 80 primary school teachers. The additional section of the factorial analysis dealt with two extracted components totaling $75.60 \%$ of the variance. Component 1 derived $41.71 \%$, whereas component 2 gained $33.89 \%$.

Table 4. The PCA of Primary School Teachers' Motivation and Performance Improvement

\begin{tabular}{cccccccc}
\hline Dimension & \multicolumn{2}{c}{ Initial Eigen values } & \multicolumn{3}{c}{$\begin{array}{c}\text { Extraction Sums of Squared } \\
\text { Loadings }\end{array}$} & $\begin{array}{c}\text { Rotation Sums } \\
\text { of Squared } \\
\text { Loadings }\end{array}$ \\
\cline { 2 - 8 } & Total & $\begin{array}{c}\text { Varian } \\
\text { ce (\%) }\end{array}$ & Cum. (\%) & $\begin{array}{c}\text { Tota } \\
1\end{array}$ & Variance (\%) & Cum. (\%) & Total \\
\hline Physicality & 2.503 & 41.711 & 41.711 & 2.503 & 41.711 & 41.711 & 2.202 \\
\hline Intellectuality & 2.034 & 33.898 & 75.609 & 2.034 & 33.898 & 75.609 & 2.042 \\
\hline Sociability & 1.229 & 20.485 & 96.094 & 1.229 & 20.485 & 96.094 & 1.664 \\
\hline Emotionality & .234 & 3.906 & 100.000 & .234 & 3.906 & 100.000 & 1.813 \\
\hline Personality & 3.402 & 5.670 & 100.000 & 3.402 & 5.670 & 100.000 & 1.856 \\
\hline Moral Ability & -1.068 & -1.780 & 100.000 & 1.068 & 1.780 & 100.000 & 1.207 \\
\hline \multicolumn{7}{c}{ Extraction Method: Principal Component Analysis. }
\end{tabular}

a. When components are correlated, sums of squared loadings cannot be added to obtain a total variance.

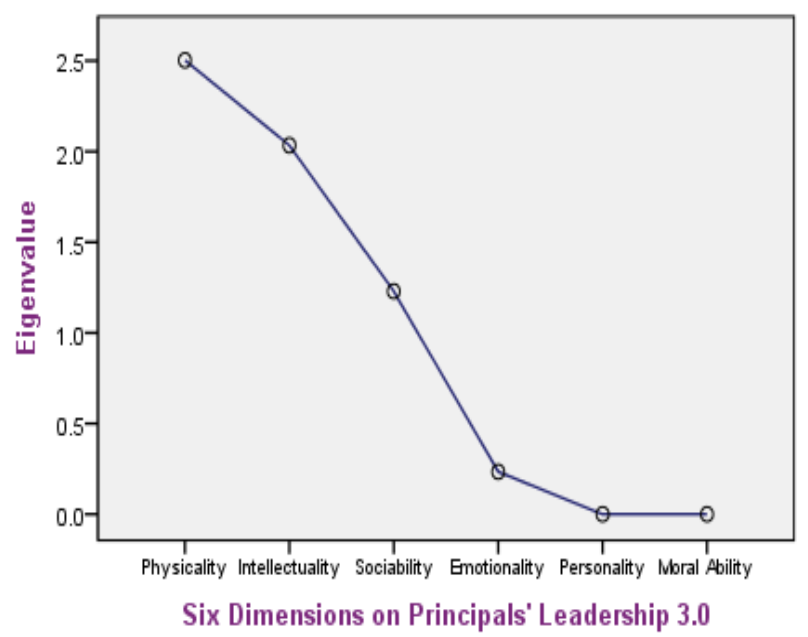

Figure 1. Scree Plot of Six Dimensions on Principals' Leadership 3.0 
To acquire an interpretation of these components, the oblimin rotation was set forth. The rotated solution compassed the presence of simple arrangement with either components that revealed a number of squared loadings or six dimensions that weighted consequentially upon component 1 solely. The interpretation of both components was analytical with the pilot outputs on the primary school teachers measure, whichever component 1 boundlessly displayed the positive affect items and component 2 alternatively boundlessly displayed the negative affect items. Nevertheless, there was a slight negative correlation between two factors, where $r=-.03$. These facts corresponded with the applicability of both positive and negative affects to be separated measures.

Table 5. Pattern - Structure Matrix for PCA with Oblimin Rotation of Two Factors of Leadership 3.0

\begin{tabular}{|c|c|c|c|c|c|}
\hline \multirow[t]{2}{*}{ Dimension } & \multicolumn{2}{|c|}{ Pattern coefficients } & \multicolumn{2}{|c|}{$\begin{array}{c}\text { Structure } \\
\text { coefficients }\end{array}$} & \multirow[t]{2}{*}{ Communalities } \\
\hline & $\begin{array}{c}\text { Component } \\
1\end{array}$ & $\begin{array}{c}\text { Component } \\
2\end{array}$ & $\begin{array}{c}\text { Component } \\
1\end{array}$ & $\begin{array}{c}\text { Component } \\
2\end{array}$ & \\
\hline 1. Physicality & .873 & N/A & 1.000 & $\mathrm{~N} / \mathrm{A}$ & -.079 \\
\hline $\begin{array}{c}4 . \\
\text { Emotionality }\end{array}$ & .873 & N/A & 1.000 & N/A & .376 \\
\hline 3. Sociability & .661 & .432 & N/A & 1.000 & .846 \\
\hline 5. Personality & -.348 & .905 & N/A & 1.000 & .443 \\
\hline $\begin{array}{c}2 . \\
\text { Intellectuality }\end{array}$ & -.348 & .905 & $\mathrm{~N} / \mathrm{A}$ & $\mathrm{N} / \mathrm{A}$ & .143 \\
\hline $\begin{array}{l}\text { 6. Moral } \\
\text { Ability }\end{array}$ & .546 & .452 & .349 & N/A & 1.000 \\
\hline
\end{tabular}

Note: major loadings for each item were in boldface

This research discussed the principals' leadership 3.0 that was accordingly significant to enhance the primary school teachers' motivation and performance. For those teachers who had a high motivation would have taught better and had a satisfaction [13]. Having a good performance in the working-place might be influential either satisfaction and motivation aspects [14]. Hence, a good educational leadership and management performance would influence teachers and supporting staff at school as well [15]. At a school's organization, teachers' motivation closely constituted with the work satisfaction [16]. Teachers with a low motivation implicated their performance and students' learning motivation and achievement [17] [18], because teachers' satisfaction shaped a good behavior and communication in the class [19]. Having a lot of experiences on teaching would influence significantly towards teachers' creativity and increase students' academic and non-academic achievements [20] [21]. Hence, to support principals' leadership 3.0 policy, a school management should continue and support its commitment to the educational leadership behavior [22] [23] and policy.

\section{CONCLUSION}

Principals' leadership 3.0 as portrayed by the primary school principals culturally manage their leadership visibility in increasing the ethos of teachers' performance during their educational services at schools. Practicality, teachers' responsibility of the motivation and teaching performance have improved their teaching performance. However, the first research question emphasized that the principals' educational leadership 3.0 contribute an improvement towards the primary school teachers' motivation $(t=19.434 ; p=.000)$ for the pre-test and $(t=$ 
20.708; $p=.000$ ) for the post-test and performance $t=24.190 ; p=.000)$ for the pre-test and ( $t$ $=27.034 ; p=.000)$ for the post-test. The second research question concluded that the principals' physicality, intellectuality, and sociability dimensions mostly contribute the primary school teachers' motivation and performance in their teaching professionalism.

However, this study is also concerned with its limitation that accordingly corresponds with the sample size determination. Although these empirical results can be applicable gradually to other primary school managements, but this six leadership dimensions policy cannot be autocratically generalized. Being experienced to this educational leadership 3.0, however, the primary school teachers may also prepare their sense of awareness in dealing with other inspiring leadership models, such as democratic, transformational, and visionary leadership to promote a more inspiring and adaptable the educational-based school settings.

\section{REFERENCES}

[1] M. A. Mawoli and A. Y. Babandako, "An Evaluation of Staff Motivation, Dissatisfaction and Job Performance In An Academic Setting," Aust. J. Bus. Manag. Res., vol. 1, no. 9, pp. 1-13, 2011.

[2] M. H. Maruapey, "Contribution To Local Wisdom Leadership Of The National Policy On Java (Descriptive Study Against Election And Designation Of President Of The Republic Of Indonesia)," Int. J. Sci. Technol. Res., vol. 5, no. 6, pp. 254-258, 2016.

[3] Dahliani, I. Soemarno, and P. Setijanti, "Local wisdom in built environment in globalization era," Int. J. Educ. Res., vol. 3, no. 6, pp. 157-166, 2015.

[4] J. Sudarjat, T. Abdullah, and W. Sunaryo, "Supervision, Leadership, and Working Motivation to Teachers' Performance," Int. J. Manag. Stud. Res., vol. 3, no. 6, pp. 146$152,2015$.

[5] G. Eyal, O.; Roth, "Principals' leadership," J. Educ. Adm., vol. 49, no. 3, pp. 256-275, 2011.

[6] Samsu and Rusmini, "The Influence of Principals' Leadership Styles on School Innovation in Jambi (Case Study in Several Senior High Schools in Jambi)," Al-Ta'lim J., vol. 23, no. 1, pp. 52-64, 2016.

[7] G. A. Gobena, "Attitude of School Principals, Supervisors and Mentees towards Action Research as Reflective Practices," Int. J. Instr., vol. 10, no. 1, pp. 3-20, 2017.

[8] A. Khorsidi, S. M. Mirzamani, and H. D. Esfahani, "Effective Factors in Enhancing School Managers' Job Motivation,” Iran. J. Psychiatry, vol. 6, no. 4, pp. 151-157, 2011.

[9] F. Eres, "Relationship between Teacher Motivation and Transformational Leadership Characteristics of School Principals," Int. J. Educ., vol. 3, no. 2, pp. 1-17, 2011.

[10] D. M. Lut, "Connection between Job Motivation , Job Satisfaction and Work Performance in Romanian Trade Enterprises," Ann. Dunarea Jos Univ. Galati, vol. XVIII, no. 3, pp. 45-50, 2012.

[11] B. Kartowagiran, "Kinerja Guru Profesional (Guru Pasca Sertifikasi)," Cakrawala Pendidik., vol. 30, no. 3, pp. 463-473, 2011.

[12] S. J. Sampson, Leaders Without Titles: The Six Powerful Attributes of Those Who Influence Without Authority. Amherst, MA: HRD Press, Inc., 2011.

[13] A. M. Usop, D. K. Askandar, M. Langguyuan-Kadtong, and D. A. S. O. Usop, "Work Performance and Job Satisfaction among Teachers," Int. J. Humanit. Soc. Sci., vol. 3, no. 5, pp. 245-252, 2013.

[14] H. Ghodrati and R. Ghaffari Tabar, "A study on effective factors on employee 
motivation,” Manag. Sci. Lett., vol. 3, no. 6, pp. 1511-1520, Jun. 2013.

[15] P. Ghenghesh, "Job Satisfaction and Motivation - What Makes Teachers Tick?," Br. J. Educ. Soc. Behav. Sci., vol. 3, no. 4, pp. 456-466, 2013.

[16] P. Selvam and S. Chamundeswari, "Motivation, Job Satisfaction and Performance Of Teachers At The Secondary Level," Int. J. Manag. Soc. Sci., vol. 3, no. 7, pp. 705-719, 2015.

[17] L. M. Njiru, "Job Satisfaction and Motivation among Teachers of Kiharu District in Kenya,” Mediterr. J. Soc. Sci., vol. 5, no. 5, pp. 135-152, 2014.

[18] A. Van Den Broeck, W. Lens, H. De Witte, and H. Van Coillie, "Unraveling the importance of the quantity and the quality of workers' motivation for well-being: A person-centered perspective," J. Vocat. Behav., vol. 82, no. 1, pp. 69-78, 2013.

[19] K. Koutrouba and M. Michala, "Professional Satisfaction of Secondary Education Teachers: The Case of Greece," Int. J. Instr., vol. 10, no. 2, pp. 85-102, 2017.

[20] R. Setiawan, "The Influence of Income, Experience, and Academic Qualification on the Early Childhood Education Teachers' Creativity in Semarang, Indonesia.," Int. J. Instr., vol. 10, no. 4, pp. 39-50, 2017.

[21] Y. Gelisli, D. K. Baidrahmanov, L. Beisenbaeva, and M. Sultanbek, "Determination of the High School Students' Attitudes towards Their Teachers,” Int. J. Instr., vol. 10, no. 4, pp. 361-378, 2017.

[22] K. S. Huggins, H. W. Klar, H. L. Hammonds, and F. C. Buskey, "Developing Leadership Capacity in Others : An Examination of High School Principals ' Personal Capacities for Fostering Leadership," Int. J. Eaducation Policy Leadersh., vol. 12, no. 1, pp. 1-15, 2017.

[23] V. Mehdinezhad and M. Mansouri, "School Principals' Leadership Behaviours and its Relation with Teachers' Sense of Self-Efficacy," Int. J. Instr., vol. 9, no. 2, pp. 51-60, 2016. 